\title{
Astyanax guaricana (Ostariophysi: Characidae), a new species from the rio Cubatão drainage, Paraná State, Southern Brazil
}

\author{
Carlos A. M. Oliveira ${ }^{1}$, Vinícius Abilhoa ${ }^{2}$ and Carla S. Pavanelli ${ }^{1}$
}

In this paper we describe a new species of Astyanax collected in the Atlantic Rainforest, in tributaries to the rio Cubatão, coastal basin of the Paraná State, Brazil. The new species presents a combination of characters that allows its allocation in the A. scabripinnis species complex and differs from congeners by the possession of 18 to 22 branched anal-fin rays; 40 to 43 perforated scales in lateral line; dentary teeth decreasing abruptly in size from the fifth tooth; 15 to 17 circumpeduncular series of scales and two vertical humeral spots.

Nesse trabalho é descrita uma espécie nova de Astyanax coletada na Floresta Atlântica, em tributários do rio Cubatão, bacia costeira do estado do Paraná, Brasil. A espécie nova possui uma combinação de caracteres que permite sua inclusão no complexo A. scabripinnis e difere das congêneres por apresentar 18 a 22 raios ramificados na nadadeira anal; 40 a 43 escamas perfuradas na linha lateral; dentes do dentário reduzindo de tamanho abruptamente a partir do quinto dente; 15 a 17 séries de escamas circumpedunculares e duas manchas umerais verticais.

Key words: Astyanax ribeirae, Astyanax scabripinnis, Characiformes, Taxonomy.

\section{Introduction}

Astyanax Baird \& Girard, 1854 is the most specious genus of characiform fishes (Garavello \& Sampaio, 2010), composed of almost 140 valid species (Eschmeyer \& Fricke, 2013), and distributed from Southern United States to Argentina (Lima et al., 2003; Casciotta et al., 2005). The current definition of this genus is based on a combination of characters proposed by Eigenmann $(1917,1921)$ : "two rows of premaxillary teeth, five teeth in the inner premaxillary series, lateral line complete, adipose fin present, and caudal fin naked". However, according to various authors, Astyanax cannot be considered a monophyletic unit (e.g., Weitzman \& Malabarba, 1998; Calcagnotto et al., 2005; Mirande, 2010; Javonillo et al., 2010). Despite of that, Astyanax is diverse and widespread in the freshwaters of the Atlantic Rainforest, and the taxonomic status of several species is not clear (Menezes et al., 2007).

The Atlantic Rainforest is one of the most diversified and endangered ecosystems in the world (Myers et al., 2000), which originally covered a wide strip of the Brazilian coastline (Morellato $\&$ Haddad, 2000). Fish species richness registered in the Atlantic Rainforest streams is high (Abilhoa et al., 2011), as a result of the great number of independent coastal drainages (or groups of basins), and the isolating effect of mountains and seawater among coastal rivers (Menezes et al., 2007).

Examination of Astyanax samples housed at the MHNCI collection allowed the discovery of an undescribed species from the Atlantic Rainforest drainage. The nee species fits the definition of the Astyanax scabripinnis species complex proposed by Bertaco \& Lucena (2006): body deepest and heaviest in area proximate to middle of pectoral fins, head heavy, snout short, body depth smaller than $41 \%$ of SL (usually $30-33 \%$ of SL), lower number of branched anal-fin rays (13-23, usually $17-18$, rarely 22-23), presence of one or two humeral spots, and a dark, midlateral body stripe extending to the tip of the middle caudal-fin rays. This paper intends to formally describe this new Astyanax species.

\section{Material and Methods}

Counts and measurements were taken according to Fink \& Weitzman (1974) and Menezes \& Weitzman (1990), except for number of scales series below the lateral line, which follows Bertaco \& Lucena (2006). Additional measurements include:

${ }^{1}$ Universidade Estadual de Maringá, Departamento de Biologia. Programa de Pós-Graduação em Ecologia de Ambientes Aquáticos Continentais (PEA), Núcleo de Pesquisas em Limnologia, Ictiologia e Aquicultura (Nupélia). Av. Colombo, 5790, 87020-900 Maringá, PR, Brazil. carlos.oliveira.itape@gmail.com(CAMO), carlasp@nupelia.uem.br(CSP).

${ }^{2}$ Museu de História Natural Capão da Imbuia (MHNCI), Grupo de Pesquisas em Ictiofauna (GPIc). Rua Prof. Benedito Conceição 407, 82.810-080 Curitiba, PR, Brazil. vabilhoa@uol.com.br 
(1) head depth, measured vertically at distal tip of supraocciptal process; (2) distance from distal tip of supraocciptal process to pelvic-fin origin; (3) distance from pectoral- to dorsal-fin origins; (4) distance from dorsal- to anal-fin origins; (5) distance from the end of dorsal-fin base to anal-fin origin; (6) distance from pectoral- to pelvic-fin origins; (7) distance from pelvic- to anal-fin origins; and (8) distance from anal- to adipose-fin origins. Measurements were taken point-to-point using a digital caliper to the nearest $0.1 \mathrm{~mm}$, on the left side of the fish. All measurements are expressed as percentages of SL, except those subunits of the head, which are expressed as percentages of head length (HL). In the text proportions are rounded to $0.1 \%$ and the count of each character is followed by their frequency in parentheses. Asterisks indicate data of the holotype.

Osteological analyses were based on cleared and stained (c\&s) specimens according to Taylor \& Van Dyke (1985). Vertebrae counts include Weberian apparatus, counted as four elements, while the ossification of the caudal complex $(\mathrm{PU} 1+\mathrm{U} 1)$ was counted as a single element.

Institutional abbreviations are: CAS (California Academy of Sciences, San Francisco), DZSJRP (Departamento de Zoologia e Botânica, Universidade Estadual Paulista "Júlio de Mesquita Filho", câmpus de São José do Rio Preto, São José do Rio Preto), DZUFMG (Departamento de Zoologia, Universidade Federal de Minas Gerais - Belo Horizonte), LBP (Laboratório de Genética e Biologia de Peixes, Universidade Estadual Paulista "Júlio de Mesquita Filho", Botucatu), MCP (Museu de Ciências e Tecnologia, Pontifícia Universidade Católica do Rio Grande do Sul, Porto Alegre), MHNCI (Museu de História Natural Capão de Imbuia, Prefeitura Municipal de Curitiba, Curitiba), MNRJ (Museu Nacional, Universidade Federal do Rio de Janeiro, Rio de Janeiro), MZUSP (Museu de Zoologia da Universidade de São Paulo, São Paulo), NUP (Coleção Ictiológica do Núcleo de Pesquisas em Limnologia, Ictiologia e Aquicultura, Universidade Estadual de Maringá), UFRGS (Departamento de Zoologia, Universidade Federal do Rio Grande do Sul, Porto Alegre). Data from comparative material of $A$. jenynsii and A. intermedius follow Bertaco \& Malabarba (2001) and Melo (2001) respectively, and data from remaining species of A. scabripinnis complex were taken from original descriptions. Meristic data of Astyanax ribeirae were taken by direct examination of specimens (see Comparative material).

\section{Results}

\section{Astyanax guaricana, new species Figs. 1-2}

Astyanax sp. -Abilhoa \& Bastos, 2009: 9, 10, 14 [Brazil, Paraná State; rio Cubatão checklist and identification key].

Holotype. MZUSP 112224, 95.6 mm SL, Paraná State, municipality of São José dos Pinhais, Arraial, Guaricana Reservoir, affluent of the rio Cubatão, 2542'29"S 4858'25'W, Feb 1986, J. C. Ribeiro \& A. Carneiro.
Paratypes. MHNCI 4712, 1, 90.7 mm SL, Apr 1985, J. C. Ribeiro \& A. Dambros, same locality as the holotype. MHNCI 5145, 1, 66.5 mm SL, MHNCI 5146, 1, $76.1 \mathrm{~mm}$ SL, MHNCI 5147 1, $63.9 \mathrm{~mm}$ SL, MHNCI 5148, 1, $60.3 \mathrm{~mm}$ SL, MHNCI 5149, 1, $69.2 \mathrm{~mm}$ SL, MHNCI 5150, 1, $69.3 \mathrm{~mm}$ SL, MHNCI 5151, 1, $56.0 \mathrm{~mm} \mathrm{SL}$, MHNCI 5152, 1, $63.8 \mathrm{~mm}$ SL, MHNCI 5153, 1, $62.1 \mathrm{~mm} \mathrm{SL}$, MHNCI 5154, 1, $64.8 \mathrm{~mm}$ SL, MHNCI 5155, 1, $65.0 \mathrm{~mm} \mathrm{SL}$, MHNCI 5156, 1, $60.8 \mathrm{~mm}$ SL, MHNCI 5169, $1 \mathrm{c \& s}, 61.5 \mathrm{~mm}$ SL, MHNCI 5170, 1 c\&s, 69.0 mm SL, MHNCI 5236, 1, 68.7 mm SL, Dec 1985, J. C. Ribeiro \& J. C. Carneiro, same locality as the holotype. MHNCI 5361, $1 \mathrm{c \& s}, 75.3 \mathrm{~mm}$ SL, MHNCI 5370, 1, $76.5 \mathrm{~mm}$ SL. MHNCI 5375, 1, $84.0 \mathrm{~mm} \mathrm{SL}$, collected with the holotype. MHNCI 11713, 1, $74.6 \mathrm{~mm}$ SL, Paraná State, municipality of Guaratuba, rio São João, affluent of the rio Cubatão, 2548'44"S 48 54'55'W, 31 Oct 1996, W. B. Wosiack \& V. Abilhoa. MZUSP 112225, 10, 60.8$77.2 \mathrm{~mm}$ SL, Dec 1985, J. C. Ribeiro \& J. C. Carneiro, same locality as the holotype. NUP 14319, 9, 59.3-75.0 mm SL, Dec 1985, J. C. Ribeiro \& J. C. Carneiro, same locality as the holotype.

Diagnosis. Astyanax guaricana is member of Astyanax scabripinnis species complex sensu Bertaco \& Lucena (2006). The new species differs from congeners of the $A$. scabripinnis species complex, except $A$. intermedius, $A$. laticeps, $A$. paranae and $A$. varzeae by having higher number of lateral line scales, 40 to 43 scales (vs. less than 39 scales in A. brachypterygium, A. burgerai, A. courensis, A. cremnobates, A. epiagos, $A$. goyanensis, A. ita, A. jacobinae, A. jenynsii, A. jordanensis, $A$. leonidas, A. microschemos, A. obscurus, A. ojiara, A. paris, $A$. pirapuan, A. rivularis, A. scabripinnis, A. totae, and A. troya). Only A. obscurus and A. ojiara have a maximum of 39 lateral line scales. A. guaricana differs from A. ojiara, by having 15 to 17 circumpeduncular scales (vs. 13 to 14 scales) and A. obscurus, by having 9 to 15 scales covering base of anal fin ( $v s .6$ to 9 scales). Astyanax guaricana differs from A. intermedius, $A$. laticeps and $A$. paranae by having two vertical humeral spots ( $v s$. a single humeral spot in A. paranae and A. intermedius, which is horizontally oval with narrow and vertical anterior extension in A. laticeps); from A. varzeae by males having hooks on the anal fin ( $v s$. hooks absent), by a shorter prepectoral distance (23.7-26.5\% vs. 26.5-32.0\% SL), shorter head length (23.9-26.6\% vs. 27.1-29.7\% SL), and longer snout length (23.3-27.9\% vs. 16.4-23.3\% head length). Besides Astyanax guaricana, only $A$. laticeps and $A$. ribeirae are sympatric. $A$. ribeirae possess one humeral spot ( $v s$. two in A. guaricana) and 34 to 38 lateral line scales ( $v s .40$ to 43 in A. guaricana).

Description. Morphometric data presented in Table 1. Maximum standard length $95.6 \mathrm{~mm}$. Body elongated and compressed, deeper and wider close to a half of pectoral-fin length. Dorsal profile straight or slightly convex between vertical through posterior nostrils and supra-occipital process, convex from this point until end of dorsal fin, and slightly convex between dorsal and adipose fins. Ventral profile convex between tip of snout and origin of pelvic fin, straight between pelvic and anal fins, straight along base of anal fin. Caudal peduncle short, dorsal and ventral margin slightly concave.

Snout rounded from upper lip to vertical anterior to nostrils. Head small. Mouth terminal. Maxillary bone extending beyond 


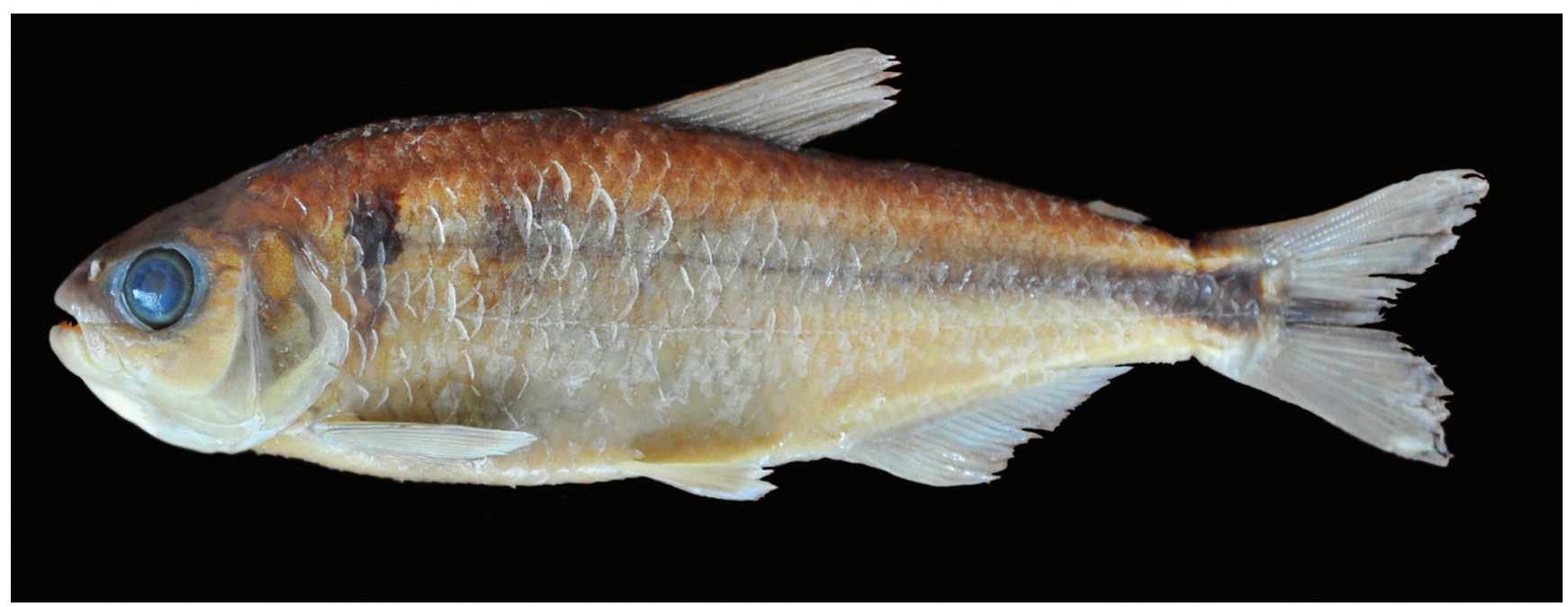

Fig. 1. Astyanax guaricana, holotype, MZUSP 112224, $95.6 \mathrm{~mm}$ SL, Brazil, Paraná State, rio Arraial, 2542'29'S 4858'25”'W, at Reservoir of Guaricana Dam affluent of the rio Cubatão, coastal basin.

vertical anterior to orbit, slightly curved and forming an angle of approximately $45^{\circ}$ relative to longitudinal axis of body. Anterior region of maxillary bone forming an angle around $90^{\circ}$ with premaxillary bone, when mouth opened. Posteroventral margin of the third infraorbital close to the preoperculum, leaving small bare area between edge of these bones.
Premaxilla with two series of teeth, outer with $4 *(22), 5$ (12) or 6(1) teeth with three or five cusps. Inner series with five teeth, with teeth of symphysis asymmetric with four or five cusps, commonly five, and lateral teeth with five or seven cusps. Maxillary bone edentulous*(8) or with 1(29) tooth with three cusps. Dentary bone with five larger anterior teeth,

Table 1. Morphometric data of Astyanax guaricana. $\mathrm{SD}=$ Standard deviation, $\mathrm{N}=36$.

\begin{tabular}{|c|c|c|c|}
\hline & \multirow{2}{*}{ Holotype } & \multicolumn{2}{|c|}{ Paratypes } \\
\hline & & Range & Mean \pm SD \\
\hline Standard length $(\mathrm{mm})$ & 95.6 & $56.0-95.6$ & 69.5 \\
\hline \multicolumn{4}{|c|}{ Percentages of Standard Length } \\
\hline Predorsal distance & 50.1 & 47.9-52.7 & $50.3 \pm 1.2$ \\
\hline Prepelvic distance & 46.4 & 46.4-51.4 & $49.1 \pm 1.2$ \\
\hline Prepectoral distance & 24.2 & $23.7-26.5$ & $24.7 \pm 0.7$ \\
\hline Preanal distance & 64.5 & $64.0-70.0$ & $66.5 \pm 1.3$ \\
\hline Body depth & 29.3 & 29.3-35.7 & $32.7 \pm 1.4$ \\
\hline Caudal peduncle depth & 10.1 & $9.0-12.4$ & $10.6 \pm 0.6$ \\
\hline Caudal peduncle length & 16.7 & $14.1-17.9$ & $16.2 \pm 0.9$ \\
\hline Dorsal-fin length & 22.3 & $18.1-26.0$ & $22.5 \pm 1.7$ \\
\hline Pelvic-fin length & 15.1 & $13.8-16.7$ & $15.1 \pm 0.8$ \\
\hline Pectoral-fin length & 17.5 & $15.4-22.1$ & $18.4 \pm 1.5$ \\
\hline Anal-fin length & 15.9 & $13.6-18.8$ & $16.2 \pm 1.2$ \\
\hline Length of anal-fin base & 23.1 & $22.9-27.5$ & $24.4 \pm 0.9$ \\
\hline Head length & 25.6 & $23.9-26.6$ & $25.1 \pm 0.6$ \\
\hline Distance from eye to dorsal fin & 38.3 & $35.8-41.4$ & $38.3 \pm 1.3$ \\
\hline Distance from dorsal-fin origin to caudal-fin origin & 49.9 & $44.3-52.1$ & $49.4 \pm 1.7$ \\
\hline Distance from pectoral-fin origin to dorsal-fin origin & 37.0 & $37.0-41.1$ & $38.8 \pm 1.2$ \\
\hline Distance from dorsal-fin origin to anal-fin origin & 32.5 & $32.5-37.5$ & $34.9 \pm 1.2$ \\
\hline Distance from the end of dorsal-fin base to anal-fin origin & 25.5 & $25.5-29.9$ & $27.8 \pm 1.0$ \\
\hline Distance from supra-occipital process to pelvic-fin origin & 35.0 & 34.9-39.6 & $37.7 \pm 1.2$ \\
\hline Distance from pectoral-fin origin to pelvic-fin origin & 23.1 & $23.1-27.2$ & $25.2 \pm 1.0$ \\
\hline Distance from pelvic- to anal-fin origins & 19.0 & $17.5-22.2$ & $19.4 \pm 1.1$ \\
\hline Distance from anal-fin origin to adipose-fin origin & 29.5 & $29.2-33.0$ & $30.8 \pm 0.9$ \\
\hline \multicolumn{4}{|c|}{ Percentages of Head Length } \\
\hline Head depth & 104.9 & 104.9-130.7 & $116.4 \pm 5.3$ \\
\hline Snout length & 26.0 & $23.3-27.9$ & $25.9 \pm 1.1$ \\
\hline Upper jaw length & 40.5 & $38.0-44.3$ & $40.6 \pm 1.4$ \\
\hline Orbital diameter & 30.5 & $30.5-38.1$ & $35.3 \pm 1.6$ \\
\hline Interorbital distance & 32.7 & $32.7-40.9$ & $35.8 \pm 2.0$ \\
\hline
\end{tabular}


followed by two to four smaller; teeth of symphysis with five or seven cusps, lateral teeth with four, five or seven cusps; smaller teeth conical or with three cusps. Size of dentary teeth varies abruptly from the fifth tooth. All teeth have a central cusp greater than laterals (Fig. 2).

Dorsal-fin rays ii,8(1) or $9 *(36)$ rays [mean $=36, n=37]$. First unbranched ray with about a half-length of second ray. Distal margin of dorsal fin straight, its origin slightly posterior to first half standard length. Adipose fin at vertical through origin of last anal-fin rays. Anal-fin rays iii(17) or iv*(20), 18(1), 19*(8), $20(10), 21(15)$, or 22(3) [mean=21, $n=37]$. Origin of anal fin posterior to vertical through last dorsal-fin rays. Pectoral-fin rays i,8(4), $9(2), 10(5), 11(4)$, or $12 *(22)$ [mean=12, $n=37$ ], its origin slightly anterior to posterior margin of opercle, when adpressed not reaching origin of pelvic fin. Pelvic-fin rays i, $7 *(26)$ or $8(11)$ [mean $=7, n=37]$, its origin anterior to vertical through dorsal-fin origin, when adpressed not reaching origin of anal fin.

Caudal fin forked, with lobes similar in length and i,9/8,i* rays $(n=37)$. Dorsal procurrent rays $10(1)$ or $12(2)$ and ventral procurrent rays 10(2) or 11(1).

Scales cicloid, moderately large. Lateral line complete, with 40(3), 41(12), 42(17), or 43*(5) [mean=42, $n=37$ ] perforated scales. Series of scales above lateral line $6(1), 7^{*}(34)$, or $8(2)$ [mean $=7, \mathrm{n}=37$ ]; below $5 *(11)$ or $6(26)$ [mean $=6, \mathrm{n}=37$ ]. Predorsal scales 12(4), 13(12), 14*(17), or 15(4) [mean=14, $\mathrm{n}=37]$. Circumpeduncular scales $15^{*}(8), 16(18)$, or $17(11)$ [mean $=16, n=37]$. Unique series of scales covering base of anal fin with $9(6), 10 *(7), 11(8), 12(7), 13(5), 14(2)$, or 15(2) [mean $=11, \mathrm{n}=37]$.

Precaudal vertebrae 18(3), caudal 21(1) or 22(2) and total 39(1) or 40(2). Supraneurals 6(3). First gill arch with 6(4), $7 *(24)$ or 8(9) gill rakers on upper branch, 1 on intermediary cartilage and 10(2), 11(31) or 12*(4) on lower branch [mean= $7+\mathrm{i}+11, \mathrm{n}=37]$.

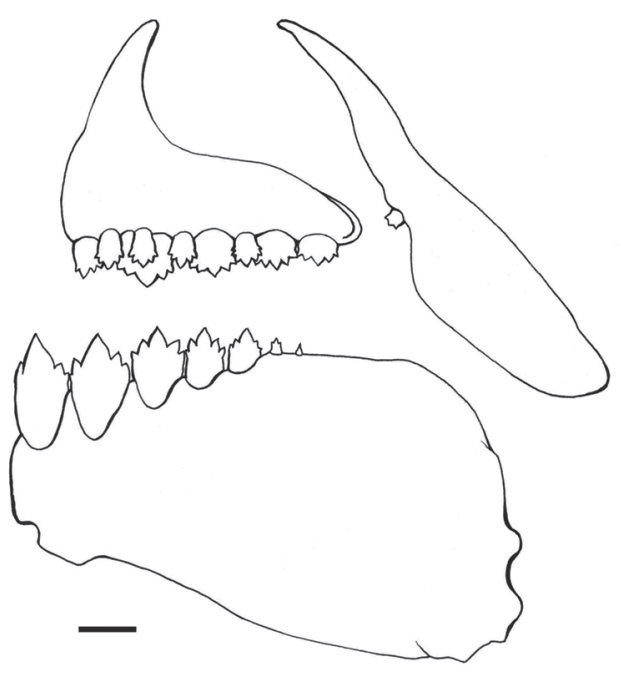

Fig. 2. Astyanax guaricana, MHNCI 5170, paratype, $69.0 \mathrm{~mm}$ SL, premaxillary, maxillary and dentary bones, left side, lateral view. Scale bar $=1 \mathrm{~mm}$
Color in alcohol. Dorsal and dorsolateral region of head and trunk yellowish-brown, ventrolateral and ventral region of head and trunk lighter yellowish-brown. Two vertical black humeral formed by dermal chromatophores. Anterior spot conspicuous, vertically elongated with upper portion broader and more evident than lower portion. Posterior humeral spot diffuse, with variable shape rounded, not ventrally surpassing lateral-line. Lateral band black, also formed by dermal chromatophores, from humeral region, just after second vertical spot, to posterior tip of median caudal-fin rays, widening upward and downward on caudal peduncle, forming a black spot.

Sexual dimorphism. Both sexes with similar color pattern. Hooks on the anal fin present only in males, from the last unbranched ray until the $10^{\text {th }}$ branched.

Distribution. Astyanax guaricana is known from tributaries of the rio Cubatão, coastal basin of Paraná State (Fig. 3).

Etymology. The specific epithet guaricana refers to the typelocality of the species, the Guaricana Reservoir of Paraná State. A noun in apposition.

\section{Discussion}

Astyanax guaricana represents the second record of the A. scabripinnis species complex sensu Bertaco \& Lucena, 2006 in the rio Cubatão basin. The first was A. laticeps (Cope, 1894), recently redescribed by Bertaco \& Lucena (2010) who expanded its distribution to this river drainage, in the southern Paraná State.

We found $A$. ribeirae also occurs throught coastal basins of Paraná State, including an affluent of the rio Cubatão (MCP 12841, MCP 30702, MHNCI 7021, NUP 9742 and NUP 10245). Previously A. ribeirae was considered endemic to the basin of the rio Ribeira de Iguape (Oyakawa et al., 2006; Menezes et al., 2007).

Although extensive collections have been made in the Atlantic Rainforest drainages of Southern Brazil in the last years, A. guaricana was not recorded in any other place. The discovery of $A$. guaricana supports the hypothesis that the river basins of the Brazilian coast have a high rate of speciation and a high degree of geographic endemism (Géry, 1969; Bizerril, 1994; Abilhoa et al., 2011). Additionally, recent descriptions of Astyanax species with restricted geographical distribution confirm that the genus is still taxonomically poorly understood, suggesting that many species should be described by improving samples and the examination of scientific collections.

Comparative material examined. In addition to the comparative material listed in Haluch \& Abilhoa (2005) and Abilhoa \& Duboc (2007), the following specimens were analyzed: Astyanax brachypterygium, MCP 14367, paratypes, 24, rio Manoel Leão, affluent of rio Pelotas, municipality of Bom Jesus, Rio Grande do Sul State. Astyanax giton, MCP 14502, 10, rio Itajaí-Açu, municipality 


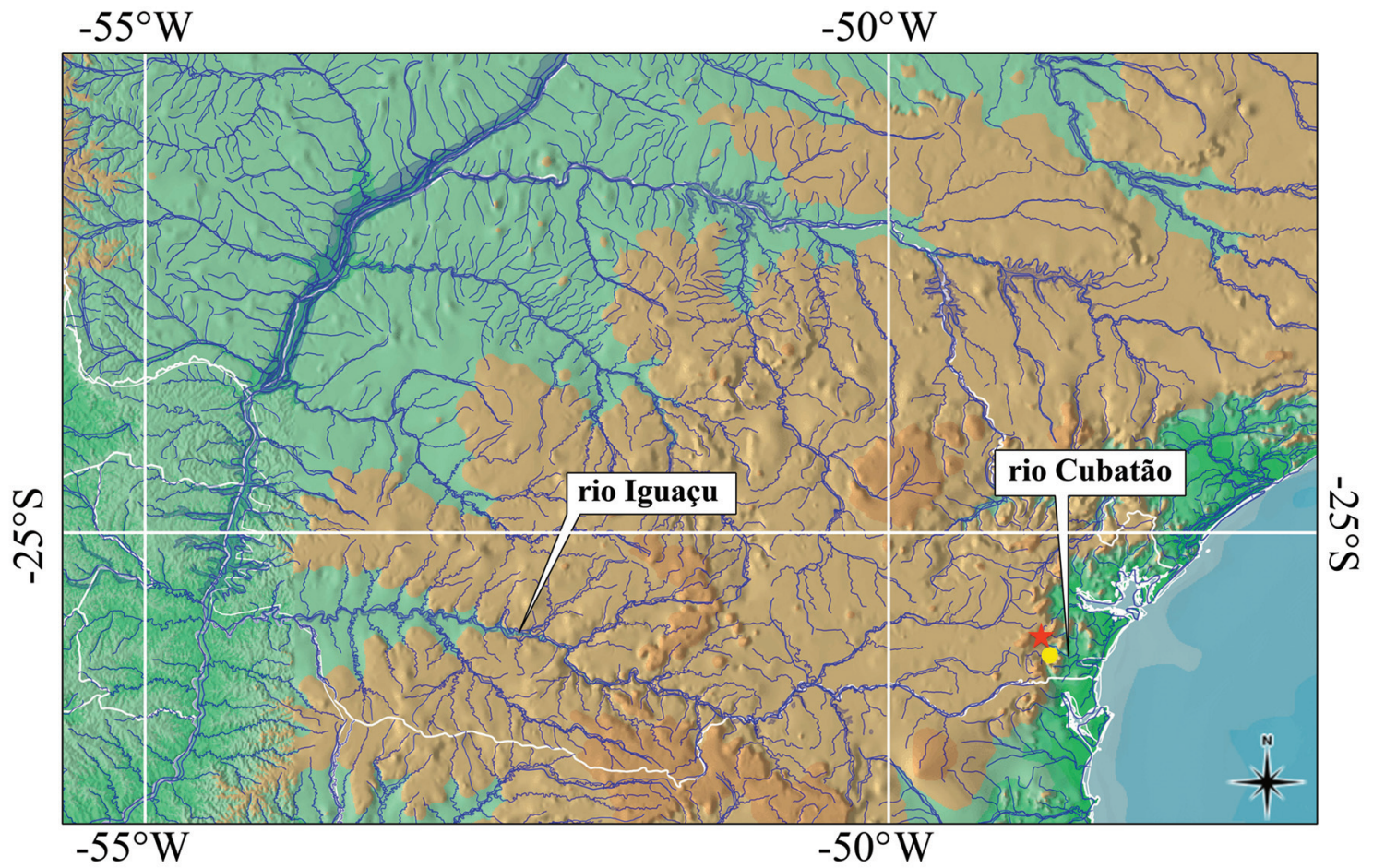

Fig. 3. Map of Paraná State and adjacent areas showing the distribution of Astyanax guaricana. The star represents the type locality (rio Arraial, at Reservoir of Guaricana dam, affluent of the rio Cubatão) and the circle represents the locality of the paratypes.

of Lontras, Santa Catarina State. Astyanax cf. hastatus, MZUSP 83448, 7, Parque Estadual da Serra do Mar, center Picinguaba, municipality of Ubatuba, São Paulo State. Astyanax intermedius, MZUSP 79403, 3, ribeirão Canjarana, municipality of Pindamonhangaba, São Paulo State. Astyanax jordanensis, NUP 1681, paratypes, 27, rio Jacu, affluent of the rio Jordão, municipality of Candói, Paraná State. Astyanax laticeps, MNRJ 24466, 2, municipality of Garuva, Santa Catarina State, affluent of right bank of the rio São João, upstream the bridge Osmar João de Novaes, coastal basin. Astyanax paranae, CAS 22555, holotype, Paraná State; CAS 22556, paratypes, 5 of 8, Paraná Sate; MHNCI 8138, 12, municipality of Palmeira, Paraná State, rio Lageado do Pitó, mouth Santa Rita, affluent of the rio Tibagi; UFRGS 6446, 136, municipality of Ponta Grossa, Paraná State, arroio Sobrado at farm Campos Gerais, affluent of the rio Lageado do Sobrado, rio Tibagi basin. Astyanax ribeirae, MCP 12841, 3 of 9, municipality of Morretes, Paraná State, rio Sagrado, affluent of rio Sambaqui. MCP 30702, 1 of 4, municipality of Antonina, Paraná State, rio Curitibaiba, affluent of rio Xaxim. MHNCI 7021, 2, municipality of Guaraqueçaba, Paraná State, rio Potinga, affluent of rio Tagaçaba. NUP 9742, 1, municipality of Antonina, Paraná State, rio Vermelho, affluent of rio Xaxim. NUP 10245 , 4, municipality of São José dos Pinhais, Paraná State, rio São João, at Reservoir of Salto do Meio dam, affluent of rio Cubatão. MZUSP 64752, 4, municipality of Sete Barras, São Paulo State, rio Ipiranga at farm Brasban, affluent of the rio Ribeira de Iguape. Astyanax rivularis, DZSJRP 5220, 10, Palácio, Serra do Cipó, affluent of the rio Cipó, municipality of Santana do Riacho, Minas Gerais State. Astyanax turmalinensis, DZUFMG 16, paratypes, 32, ribeirão do Gigante, affluent of the rio Jequitinhonha, municipality of Botumirim, Minas Gerais State. Astyanax vermilion, LBP 8319, 30, rio Almada, municipality of Ilhéus, Bahia.

\section{Acknowledgments}

We thank Weferson J. da Graça for critical reading the manuscript and Gabriel Deprá (UEM/Nupélia) for gently making the drawing. Photograph of holotype was produced by Fabiano Corrêa (UFPel). Nupélia (Núcleo de Pesquisas em Limnologia, Ictiologia e Aquicultura) also provided logistical support. Research associated with this study was supported by the Copel (Companhia Paranense de Energia) and UEM (Universidade Estadual de Maringá)/Nupélia. CSP has been supported by grants from $\mathrm{CNPq}$ (Conselho Nacional de Desenvolvimento Científico e Tecnológico). This work is part of CAMO M.Sc.dissertation.

\section{Literature Cited}

Abilhoa, V. \& L. P. Bastos. 2009. Fish, Cubatão River Basin, Atlantic Rainforest stream, Paraná, Brazil. Checklist, 5: 08-18.

Abilhoa, V. \& L. F. Duboc. 2007. A new species of the freshwater fish genus Astyanax (Ostariophysi: Characidae) from the rio Iguaçu basin, southeastern Brazil. Zootaxa, 1587: 43-52.

Abilhoa, V., R. R. Braga, H. Bornatowski \& J. R. S. Vitule. 2011. Fishes of the Atlantic Rain Forest Streams: Ecological Patterns 
and Conservation. Pp. 259-282. In: Grillo, O. \& G. Venora (Eds.). Changing Diversity in Changing Environment. Croácia, InTech.

Bertaco, V. A. \& C. A. S. Lucena. 2006. Two new species of Astyanax (Ostariophysi: Characiformes: Characidae) from eastern Brazil, with a synopsis of the Astyanax scabripinnis species complex. Neotropical Ichthyology, 4: 53-60.

Bertaco, V. A. \& C. A. S. Lucena. 2010. Redescription of Astyanax obscurus (Hensel, 1870) and A. laticeps (Cope, 1894) (Teleostei: Characidae): two valid freshwater species originally described from rivers of Southern Brazil. Neotropical Ichthyology, 8: 7-20.

Bertaco, V. A. \& L. R. Malabarba. 2001. Description of two new species of Astyanax (Teleostei: Characidae) from headwater streams of Southern Brazil, with comments on the " $A$. scabripinnis species complex". Ichthyological Exploration of Freshwaters, 12: 221-234.

Bizerril, C. R. S. F. 1994. Análise taxonômica e biogeográfica da ictiofauna de água doce do leste brasileiro. Acta Biológica Leopoldensia, 16: 51-80.

Calcagnotto, D., S. A. Schaefer \& R. DeSalle. 2005. Relationships among characiform fishes inferred from analysis of nuclear and mitochondrial gene sequences. Molecular Phylogenetics and Evolution, 36: 135-153.

Casciotta, J. R., A. E. Almirón \& M. M. Azpelicueta. 2005. Astyanax pampa (Characiformes, Characidae), a new species from the southernmost boundary of the Brazilian subregion, Argentina. Revue suisse de Zoologie, 112: 401-408.

Eigenmann, C. H. 1917. The American Characidae. Part 1. Memoirs of Museum of Comparative Zoology, 43: 1-102.

Eigenmann, C. H. 1921. The American Characidae. Part 3. Memoirs of the Museum of Comparative Zoology, 43: 208-310.

Eschmeyer, W. N. \& Fricke, R. 2012. Catalog of Fishes electronic version (13 May 2013). Available from: http:// research.calacademy.org/redirect? url=http:// researcharchive.calacademy.org/research/Ichthyology/catalog/ fishcatmain.asp

Fink, W. L. \& S. H. Weitzman. 1974. The so-called cheirodontin fishes of Central America with description of two new species (Pisces, Characidae). Smithsonian Contributions to Zoology, 172: $1-46$

Garavello J. C. \& F. A. A. Sampaio. 2010. Five new species of genus Astyanax Baird \& Girard, 1854 from Rio Iguaçu, Paraná, Brazil (Ostariophysi, Characiformes, Characidae). Brazilian Journal of Biology, 70: 847-865.

Géry, J. 1969. The fresh-water fishes of South America. Pp. 828848. In: E. J. Fittkau, J. Illies, H. Klinge, G. H. Schwabe \& H. Sioli (Eds.). Biogeography and ecology in South America. The Hague Publishers.

Haluch, C. F. \& V. Abilhoa. 2005. Astyanax totae, a new characid species (Teleostei: Characidae) from the upper rio Iguaçu basin, southeastern Brazil. Neotropical Ichthyology, 3: 383-388.
Javonillo, R., L. R. Malabarba, S. H. Weitzman \& J. R. Burns. 2010 Relationships among major lineages of characid fishes (Teleostei: Ostariophysi: Characiformes), based on molecular sequence data. Molecular Phylogenetics and Evolution, 54: 498-511.

Lima, F. C. T., L. R. Malabarba, P. A. Buckup, J. F. P. Silva, R. P. Vari, A. Harold, R. Benine, O. T. Oyakawa, C. S. Pavanelli, N. A. Menezes, C. A. Lucena, M. C. S. L. Malabarba, Z. M. S. Lucena, R. E. Reis, F. Langeani, L. Casatti, V. A. Bertaco, C. Moreira \& P. H. F. Lucinda. 2003. Genera Incertae Sedis in Characidae. Pp. 106-169. In: Reis, R. E., S. O. Kullander \& C. Ferraris Jr. (Eds.). Check List of the Freshwater Fishes of South and Central America. Porto Alegre, Edipucrs.

Melo, F. A. G. 2001. Revisão taxonômica das espécies do gênero Astyanax Baird \& Girard, 1854 (Teleostei: Characiformes: Characidae) da região da serra dos Órgãos. Arquivos do Museu Nacional, 59: 1-46.

Menezes, N. A. \& S. H. Weitzman. 1990. Two new species of Mimagoniates (Teleostei: Characidae: Glandulocaudinae), their phylogeny and biogeography and a key to the glandulocaudin fishes of Brazil and Paraguay. Proceedings of the Biological Society of Washington, 103: 380-426.

Menezes, N. A., S. H. Weitzman, O. T. Oyakawa, F. C. T. Lima, R. M. C. Castro \& M. J. Weitzman. 2007. Peixes de água doce da Mata Atlântica. São Paulo, Museu de Zoologia da Universidade de São Paulo.

Mirande, J. M. 2010. Phylogeny of the family Characidae (Teleostei: Characiformes): from characters to taxonomy. Neotropical Ichthyology, 8: 385-568.

Morellato, L. P. C. \& C. F. B. Haddad. 2000. Introduction: The Brazilian Atlantic Forest. Biotropica, 32: 786-792.

Myers, N., R. A. Mittermeier, C. G. Mittermeier, G. A. Fonseca \& J. Kent. 2000. Biodiversity hotspots for conservation priorities. Nature, 403: 853-858.

Oyakawa, O. T., A. Akama, K. C. Mautari \& J. C. Nolasco. 2006. Peixes de riachos da Mata Atlântica. Neotrópica.

Taylor, W. R. \& G. C. van Dyke. 1985. Revised procedures for staining and clearing small fishes and other vertebrates for bone and cartilage study. Cybium, 9: 107-119.

Weitzman, S. H. \& L. R. Malabarba. 1998. Perspectives about the phylogeny and classification of the Characidae (Teleostei: Characiformes). Pp. 161-170. In: L. R. Malabarba, R. E. Reis, R. P. Vari, Z. M. S. Lucena \& C. A. S. Lucena (Eds.). Phylogeny and classification of Neotropical fishes. Porto Alegre, Edipucrs.

Submitted June 22, 2012 Accepted February 25, 2013 by Luiz R. Malabarba Published June 28, 2013 